\title{
Pemanfaatan Bahan Ajar Berupa Komik dalam Pembelajaran IPS
}

\author{
Dwi Yanti Angelina ${ }^{1}$, Suhardjo $^{2}$, Ode Sofyan Hardi ${ }^{3}$ \\ ${ }^{123}$ Pendidikan Geografi Universitas Negeri Jakarta, Indonesia \\ ${ }^{1}$ Email : dwiyantiangel@gmail.com
}

\begin{abstract}
Abstrak. Penelitian ini bertujuan untuk mengetahui manfaat bahan ajar berupa komik sebagai pembelajaran IPS dalam konten geografi. Metode yang digunakan adalah metode deskriptif. Populasi dalam penelitian ini yaitu peserta didik SMPN 62 Jakarta dan sampel penelitiannya yaitu peserta didik kelas VII.5. Teknik analisis dalam penelitian ini menggunakan angket / kuesioner secara daring dengan skala likert dan uji gain yang dilakukan untuk mengetahui tingkat atau besarnya pengaruh penggunaan/pemanfaatan media komik dengan menghitung selisih skor pada saat post test dan pre test. Adapun teknik pengambilan sampel adalah simple random sampling, peserta didik kelas VII.5 berjumlah 37 peserta didik. Hasil penelitian menunjukan berdasarkan validasi oleh ahli komik dan ahli materi dinyatakan layak digunakan sebagai bahan ajar dalam proses pembelajaran IPS dengan konten geografi. Lalu, adanya pengaruh dari pemanfaatan penggunaan komik dalam pembelajaran IPS dengan konten geografi yang dapat dilihat dari perhitungan melalui uji gain dan skala likert. Hasil menunjukan adanya perbedaan yang signifikan setelah menggunakan komik dalam pembelajaran IPS dengan konten geografi di kelas VII.5 SMPN 62 Jakarta. Hal tersebut dapat dilihat dari hasil pretest dan post test yang menunjukan kategori tinggi yaitu 0.8 dalam perhitungan uji gain. Selanjutnya, melalui perhitungan skala likert, presentase jawaban responden yaitu menunjukan sebesar $80 \%$ yang termasuk kategori layak.
\end{abstract}

Kata Kunci: Pemanfaatan bahan ajar, komik, IPS

\begin{abstract}
This study aims to determine the benefits of teaching materials in the form of comics as social studies learning in geography content. The method used is descriptive method. The population in this study were students of SMPN 62 Jakarta and the research sample was students of class VII.5 totaling 37 students. The analysis technique in this study used an online questionnaire with a Likert scale and a gain test that was conducted to determine the level or magnitude of the influence of the use / utilization of comic media. The sampling technique is simple random sampling. The results of the study were based on validation by comics experts and material experts which were declared fit for use as teaching materials in the social studies learning process with geographic content. The influence of the use of comics in social studies learning with geographic content can be seen from calculations through the gain test and the Likert scale. The results of the pretest and posttest which show the high category, namely 0.8 in the calculation of the gain test. Furthermore, through the calculation of the Likert scale, the percentage of respondents' answers shows that $80 \%$ is in the feasible category.
\end{abstract}

Keywords: Utilization of teaching materials, comics, social studies learning 


\section{PENDAHULUAN}

Pendidikan memiliki peran penting bagi penerus Indonesia. Hal ini dikarenakan pendidikan dapat memberi banyak pengetahuan dan pendidikan juga dapat memberikan maupun membentuk sudut pandangan bagi kehidupan dan dapat membentuk karakter tiap individu yang mampu merencanakan masa depan dan mengambil keputusan yang tepat dalam hidup.

Menurut Undang-Undang RI. Nomor 20 Tahun 2003 tentang Sistem pendidikan Nasional, Pendidikan adalah usaha sadar dan terencana untuk mewujudkan suasana belajar dan proses pembelajaran agar peserta didik secara aktif mengembangkan potensi dirinya untuk memiliki kekuatan spiritual keagamaan, pengendalian diri, kepribadian, kecerdasan, akhlak mulia, serta keterampilan yang diperlukan dirinya, masyarakat, bangsa dan Negara. Dalam proses belajar mengajar dibutuhkan suatu bahan ajar. Bahan ajar adalah segala bentuk bahan yang digunakan untuk membantu guru dalam melaksanakan kegiatan belajar mengajar di kelas. Bahan yang dimaksud berupa tertulis maupun bahan tidak tertulis. Bahan ajar memiliki peranan yang sangat penting dalam proses pembelajaran.

Pendidikan saat ini telah memasuki kurikulum 2013, dimana peserta didik dituntut aktif dalam belajar. Namun faktanya, dalam mempelajari mata pelajaran Ilmu Pengetahuan Sosial dengan konten geografi, peserta didik cenderung lambat dalam menyerap pelajaran yang diterima, karena bahan pembelajaran seperti buku pelajaran cenderung bersifat monoton sehingga peserta didik kurang termotivasi. Menurut Heruman dalam Desi Kurniati, dkk (2010), yaitu dalam mengembangkan kreativitas dan kompetensi siswa, maka guru hendaknya dapat menyajikan pembelajaran yang efektif dan efisien sesuai dengan kurikulum dan pola pikir siswa. Pembelajaran yang efektif yaitu pembelajaran yang dapat membawa peserta didik untuk mencapai tujuan pembelajaran yang diharapkan. Sedangkan pembelajaran yang efisien yaitu pembelajaran yang berlangsung menggunakan waktu dan sumber daya yang efisien. Memberikan metode pembelajaran yang lebih variatif dan mengembangkan bahan ajar sebagai sumber belajar bagi siswa yang lebih inovatif merupakan cara agar pembelajaran dapat menjadi efektif dan efisien yaitu salah satunya dengan menggunakan bahan ajar berupa komik. Menurut Daryanto dalam Santi (2017:23), Komik didefinisikan sebagai bentuk kartun yang mengungkapkan karakter menerapkan suatu cerita dalam urutan yang erat hubungannya dengan gambar yang rancang untuk memberikan hiburan kepada pembaca. Pada awalnya komik diciptakan bukan untuk kegiatan pembelajaran, namun untuk kepentingan hiburan semata.

Dalam penelitian ini, peneliti melakukan penelitian untuk tingkat Sekolah Menengah Pertama (SMP), yaitu di SMP Negeri 62 Jakarta yang mendapatkan pelajaran geografi meskipun dalam pelajarannya masih merupakan pelajaran IPS. SMP Negeri 62 Jakarta masih menggunakan buku cetak dalam bahan ajar nya.

Lalu, alasan dipilihnya tingkat SMP karena dikutip dari Anip Dwi Saputro (2015:3), masa Sekolah Menengah Pertama merupakan masa peralihan menuju remaja sehingga memerlukan suatu media untuk meningkatkan prestasi belajar dan berpikir kritis siswa (Hurlock, 2000: Jilid 1 hal 63-65). Sudjana dan Rivai (2005:65) menyatakan bahwa buku-buku komik maupun gambar dapat dipergunakan secara efektif oleh guru-guru dalam usaha meningkatkan minat, mengembangkan pembendaharaan kata-kata dan keterampilan membaca. Selain itu, menurut Zuli Lailatul Fajriah dan Evita Anggereini (2016) Media pembelajaran yang cocok untuk siswa SMP yaitu komik karena siswa SMP cenderung menyukai media pembelajaran yang kesannya menghibur. Pentingnya komik sebagai media alternatif yang tepat untuk pembelajaran, karena keterlibatan emosi pembacanya akan sangat mempengaruhi memori dan daya ingat akan materi pelajaran yang didapat. Menurut De Porter (2000:23) dalam Zuli Lailatul Fajriah dan Evita Anggereini (2016) komik dapat diterapkan untuk menyampaikan pesan dalam berbagai ilmu pengetahuan selain penampilannya yang menarik.

Selain itu, alasan mengapa dipilihnya komik sebagai bahan ajar, karena komik sangat menarik dalam kehidupan peserta didik sehingga dapat mengenal karakter tokoh maupun cerita dari komik yang mereka baca / lihat. Lalu, peserta didik cenderung malas untuk membaca. Menurut Olynda Ade Arisma (2012) rendahnya minat baca siswa karena lebih memilih di kelas, bercerita dengan teman, dibandingkan dengan membaca buku ke perpustakaan. Rendahnya minat baca siswa disebabkan siswa kurang memiliki perasaan dan perhatian terhadap buku dan manfaat membaca. 
Angelina, dkk. Pemanfaatan Bahan Ajar Berupa Komik ...

\section{METODE}

Penulisan ini bertujuan untuk mengetahui manfaat bahan ajar berupa komik sebagai pembelajaran geografi. Penelitian ini menggunakan metode deskriptif dengan rancangan penelitian yang dikembangkan oleh Kemmis dan Mc. Taggart dalam Arikunto (2006:93). Rancangan tersebut terdiri atas tiga tahapan, yakni: perencanaan (planning), pelaksanaan (action) dan refleksi (reflection). Pada tahap perencanaan, peneliti merencanakan penelitian dengan menyusun bahan ajar berupa komik berdasarkan kurikulum, merancang instrumen penelitian (kuesioner) dan menentapkan indikator ketercapaian. Sedangkan pada tahap pelaksanaan, peneliti melaksanakan dari apa yang telah dirancang pada tahap perencanaan yaitu memberikan bahan ajar berupa komik dan menyebarkan kuesioner. Selanjutnya refleksi (reflection) yaitu melihat seberapa manfaatnya bahan ajar berupa komik dilihat dari pemberian kuesioner, pretest dan post test.

Untuk menganalisa data dari pertanyaan isi angket / kuesioner menggunakan skala likert. Hasil penilaian tersebut lalu dicari rata-ratanya selanjutnya konversikan ke pernyataan penilaian demi memastikan kualitas serta nilai kegunaan produk tersebut bersumber pada penilaian dari pengguna. standar kelayakan dijelaskan pada tabel 1.(Arikunto:2008)

Tabel 1 : Standar Kelayakan

\begin{tabular}{cc}
$\begin{array}{c}\text { Angka } \\
\text { Persentase }\end{array}$ & $\begin{array}{c}(\%) \\
\text { Keterangan }\end{array}$ \\
\hline $80 \%-100 \%$ & Amat Layak \\
\hline $61 \%<\mathrm{P} \leq 80 \%$ & Layak \\
\hline $41 \%<\mathrm{P} \leq 60 \%$ & Cukup Layak \\
\hline $21 \%<\mathrm{P} \leq 40 \%$ & Kurang Layak \\
\hline$<21 \%$ & Amat Kurang \\
\hline
\end{tabular}

Selain itu, Uji gain dilakukan untuk mengetahui tingkat atau besarnya pengaruh penggunaan/pemanfaatan media komik dengan menghitung selisih skor pada saat posttest dan pretest, pengujian nilai gain. Selanjutnya dilakukan pengklasifikasian hasil nilai ke dalam kriteria gain skor pada tabel 2 .
Tabel 2 : Kriteria Gain

\begin{tabular}{ll}
\hline Skor Kriteria & Nilai \\
\hline Tinggi & $\mathrm{g} \geq 0,7$ \\
\hline Sedang & $0,7>\mathrm{g} \geq 0,3$ \\
\hline Rendah & $\mathrm{g} \leq 0,3$ \\
\hline
\end{tabular}

Sumber : Siti Larasati (2016:64)

Dari teknik analisis tersebut, penilaian akan selesai jika nilai yang diperoleh sudah menepati aturan kelayakan dengan tingkat kelayakan dan kesesuaian materi.

\section{HASIL DAN PEMBAHASAN}

Penelitian ini dilakukan di SMP Negeri 62 Jakarta, yang terletak di Jalan Jatinegara Timur IV No.5, RT.8/RW.7, Rawa Bunga, Kecamatan Jatinegara, Kota Jakarta Timur, Daerah Khusus Ibukota Jakarta 13350.

Pemanfaatan bahan ajar berupa komik dikemas secara online atau dalam bentuk softcopy. Komik geografi ini dibuat agar pembelajaran dapat lebih menarik dan efektif dalam kegiatan belajar mengajar. Komik geografi termasuk dalam discovery learning yaitu peserta didik dituntut untuk belajar mandiri dan komik geografi adalah salah satunya. Dengan menggunakan komik geografi dapat mempermudah pemahaman peserta didik sehingga dapat meningkatkan hasil belajar peserta didik.

Adapun dalam pembuatan komik, memanfaatkan software MediBang Paint dan Adobe Photoshop. MediBang Paint digunakan untuk menggambar sedangkan Adobe Photoshop digunakan untuk meletakan panel-panel yang telah digambar dari aplikasi MediBang Paint. aplikasi Adobe Photoshop juga digunakan untuk mengedit atau memasukan tulisan agar komik terlihat lebih rapi. Komik geografi ini dibuat berdasarkan Rencana Pelaksaaan Pembelajaran (RPP) mata pelajaran IPS kelas VII.

Setelah pembuatan komik dan sebelum diberikan kepada peserta didik, komik divalidasi terlebih dahulu oleh ahli komik dan ahli materi guna memberikan saran atau komentar dari segi visual media. Ahli komik yang memvalidasi komik adalah Galang Ekaputra Larope, Komikus "Romance Punch", penerbit Kosmik dan Dani Safitra, komikus "Si Belang". Terdapat beberapa saran atau komentar sehingga perlu adanya perbaikan, adapun saran dan perbaikan yang diberikan oleh ahli komik. Begitu pula dengan komik yang divalidasi oleh ahli materi dengan validatornya yaitu Dra. Wahyuni Nurul $\mathrm{H}$ yang merupakan guru mata pelajaran IPS di SMP Negeri 62 Jakarta dan Dr. Aris Munandar, M.Si 
yang merupakan dosen Pendidikan Geografi Universitas Negeri Jakarta. Cara memvalidasi dilakukan secara online.

\section{Analisis validasi komik oleh ahli}

Komik dalam mata pelajaran IPS dengan materi geografi ini dikemas dalam format $p d f$ dan dibagikan secara online. komik geografi ini, divalidasi terlebih dahulu oleh ahli komik dan ahli materi untuk mengetahui kelayakan media komik tersebut. Proses validasi dilakukan untuk memperbaiki produk berdasarkan penilaian atau saran maupun masukan dari ahli / pakar, sehingga dihasilkan bahan ajar berupa komik dengan materi atau konten geografi yang layak digunakan dalam pembelajaran.

Hasil Validasi oleh Galang Ekaputra Larope, Komikus "Romance Punch", penerbit Kosmik

Tabel 3 : revisi komik oleh ahli komik Galang Ekaputra Larope

\begin{tabular}{ll} 
Saran/Komentar & Perbaikan/revisi \\
\hline sudah baik dan jelas & Memberi cetak \\
sebagai bahan & tebal / bold pada \\
pembelajaran. sedikit & bagian-bagian \\
masukan untuk kata & penting dalam \\
atau bagian-bagian & komik. \\
penting dari materinya & Dibagian akhir \\
teksnya bisa bold, dan & memberi gambar \\
jarak kata perkata & karakter yang \\
usahkan selalu sama & tersenyum \\
atas dan bawah. untuk & mengerti pelajaran \\
Ending nya & tersebut \\
karakternya bisa dibuat & \\
lebih bersemangat & \\
setelah mengerti & \\
pelajarannya misalnya & \\
tersenyum. &
\end{tabular}

Sumber : Hasil Penelitian Tahun 2020

Perbaikan dilakukan berdasarkan saran/komentar dari pakar. Hasil revisi dari pakar komik lebih jelasnya dapat dilihat pada gambar 2.

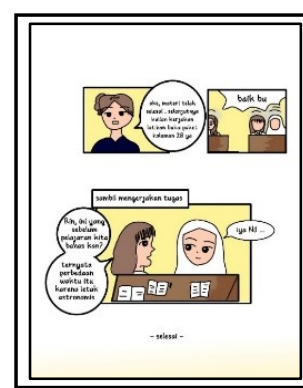

(a)

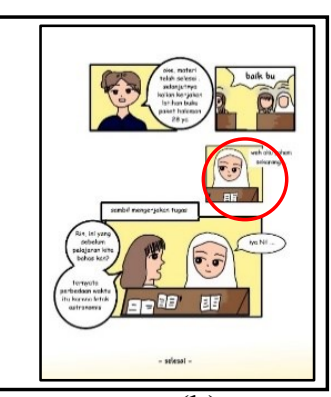

(b)
Gambar 2 : Revisi komik, (a) sebelum, (b) sesudah direvisi
Sumber : Hasil Penelitian Tahun 2020 Berdasarkan hasil validasi dari ahli komik oleh Galang Ekaputra Larop adanya saran untuk perbaikan yaitu kata atau bagian-bagian penting dari materi yaitu teksnya bisa bold dan jarak kata perkata usahkan selalu sama atas dan bawah. Untuk Ending nya karakternya bisa dibuat lebih bersemangat setelah mengerti pelajarannya misalnya tersenyum. Oleh sebab itu, penulis merevisi dengan menambahkan panel dibagian akhir yaitu dengan gambar karakter yang tersenyum mengerti pelajaran tersebut, lalu memberi cetak tebal / bold pada bagian-bagian penting dalam komik.

Hasil Validasi oleh Dani Safitra, komikus "Si Belang"

Tabel 4 : revisi komik oleh ahli komik Dani Safitra

\begin{tabular}{|c|c|}
\hline Saran/Komentar & Perbaikan/revisi \\
\hline $\begin{array}{l}\text { Yang dilingkari atas } \\
\text { coba diberi keterangan } \\
\text { waktu dan yang } \\
\text { lingkaran bawah bubble } \\
\text { text nya kalo bisa jangan } \\
\text { dempet karena beda } \\
\text { tokoh. }\end{array}$ & $\begin{array}{l}\text { Memberi } \\
\text { keterangan waktu } \\
\text { di tempat yang } \\
\text { disarankan dan } \\
\text { mengganti bubble } \\
\text { text agar tidak } \\
\text { dempet. }\end{array}$ \\
\hline $\begin{array}{lr}\text { kalau bisa } & \text { perkenalan } \\
\text { karakternya } & \text { dibuat } \\
\text { dalam adegan } & \end{array}$ & $\begin{array}{l}\text { Mengganti } \\
\text { perkenalan } \\
\text { karakter dengan } \\
\text { dibuat } \\
\text { adegan }\end{array}$ \\
\hline $\begin{array}{l}\text { tokoh bu guru di panel } \\
\text { dua halaman } 2 \text { diberi } \\
\text { gerakan gestur tangan } \\
\text { biar dinamis seperti }\end{array}$ & $\begin{array}{lr}\text { Memberi } & \\
\text { tambahan } & \text { gambar } \\
\text { gerakan } & \text { gestur } \\
\text { tangan } & \end{array}$ \\
\hline
\end{tabular}
menjelaskan sesuatu

Sumber : Hasil Penelitian Tahun 2020

Perbaikan dilakukan berdasarkan saran/komentar dari pakar. Hasil revisi dari pakar komik dapat dilihat pada gambar 4, 5 dan

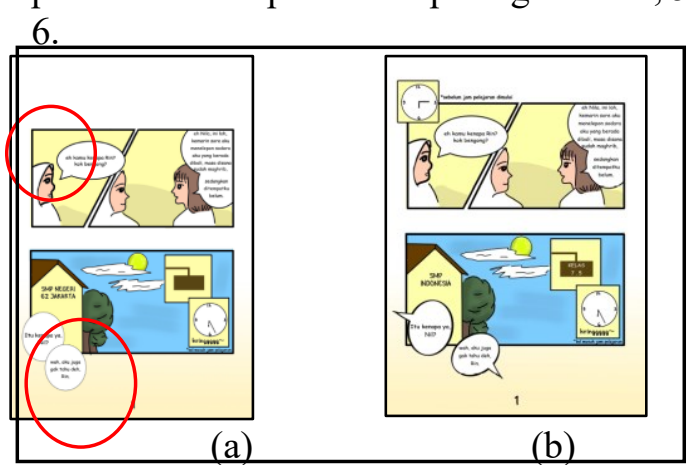

Gambar 3 : Revisi komik, (a) sebelum, (b) sesudah direvisi 
Angelina, dkk. Pemanfaatan Bahan Ajar Berupa Komik ...

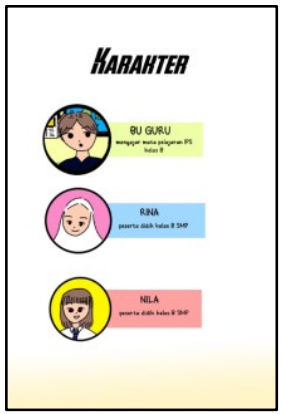

(a)

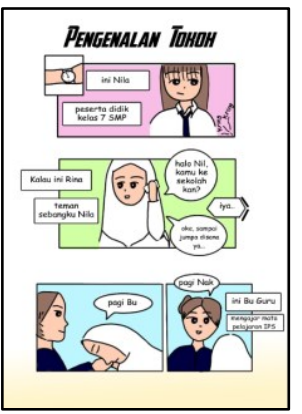

(b)
Gambar 4 : Revisi komik, (a) sebelum, (b) sesudah direvisi

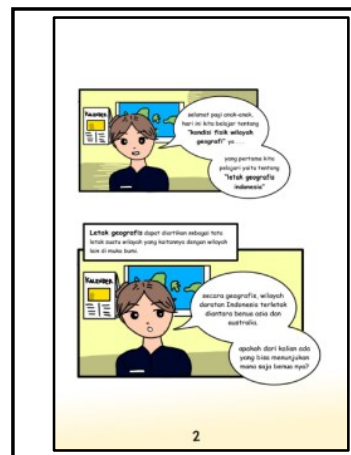

(a)

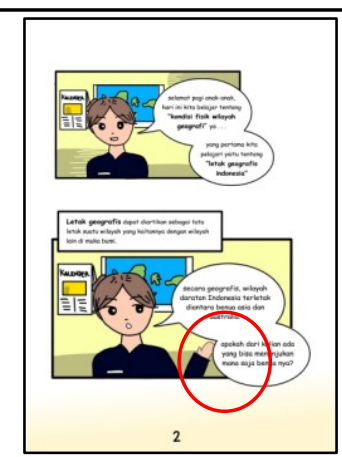

(b)
Gambar 5 : Revisi komik, (a) sebelum, (b) sesudah direvisi

Berdasarkan hasil validasi dari ahli komik oleh Dani Safitra adanya saran untuk perbaikan yaitu pada halaman1 panel 1 beri keterangan waktu dan yang lingkaran bawah bubble text nya kalo bisa jangan dempet karena beda tokoh. Lalu, perkenalan karakternya dibuat dalam adegan dan tokoh bu guru di panel 2 halaman 2 diberi gerakan gestur tangan biar dinamis seperti menjelaskan sesuatu. Sehingga, penulis merevisi dengan memberi keterangan waktu di tempat yang disarankan dan mengganti bubble text agar tidak dempet, mengganti perkenalan karakter dengan dibuat dalam adegan dan di panel 2 halaman 2 diberi tambahan gambar gerakan gestur tangan.

\section{Hasil Validasi oleh Ahli Materi}

Ahli materi yang memvalidasi komik yaitu Dra. Wahyuni Nurul $H$ dan Dr. Aris Munandar, M.Si yang dilakukan secara online.

Tabel 5: Revisi komik oleh Dra. Wahyuni Nurul

\begin{tabular}{|c|c|}
\hline Saran/Komentar & Perbaikan/revisi \\
\hline $\begin{array}{l}\text { Sudah bagus } \\
\text { dalam } \\
\text { malkmrdswe2teri } \\
\text { maupun gambar, } \\
\text { sudah sesuai }\end{array}$ & $\begin{array}{l}\text { Mengganti font } \\
\text { agar lebih mudah } \\
\text { terbaca }\end{array}$ \\
\hline
\end{tabular}

\section{dengan materi \\ untuk kelas VII \\ SMP, hanya font \\ terlihat kurang \\ rapi}

Perbaikan dilakukan berdasarkan saran/komentar dari pakar. Hasil revisi dari pakar materi lebih jelasnya dapat dilihat pada gambar berikut ini:

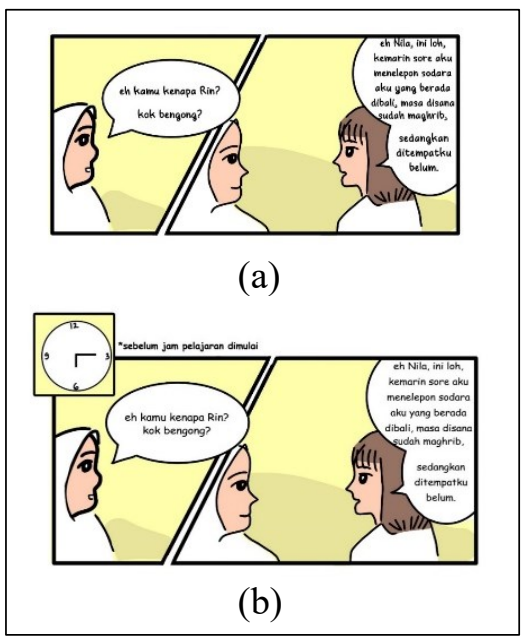

Gambar 6 : Revisi komik, (a) sebelum, (b) sesudah direvisi

Berdasarkan hasil validasi dari ahli materi yaitu Dra. Wahyuni Nurul H, guru IPS di SMP Negeri 62 memberikan saran untuk perbaikan yaitu sudah bagus dalam materi maupun gambar, sudah sesuai dengan materi untuk kelas VII SMP, hanya font terlihat kurang rapi. Sehingga, penulis merevisi dengan mengganti font agar lebih mudah terbaca.

Tabel 6 : Revisi Komik Oleh Dr. Aris Munandar, M.Si

\begin{tabular}{|c|c|}
\hline Saran/Komentar & Perbaikan/revisi \\
\hline $\begin{array}{l}\text { Untuk halaman } \\
\text { nomor 13, konsep } \\
\text { nya kurang tepat, } \\
\text { seharusnya: } \\
\text { perpaduan dua } \\
\text { budaya yang masih } \\
\text { memperlihatkan } \\
\text { unsur budaya } \\
\text { masing-masing }\end{array}$ & $\begin{array}{l}\text { Menambahkan kalimat } \\
\text { seperti yang telah } \\
\text { disarankan }\end{array}$ \\
\hline $\begin{array}{l}\text { Pada halaman } 7 \text {, } \\
\text { konsep bujur dan } \\
\text { lintang terbalik }\end{array}$ & $\begin{array}{l}\text { Memperbaiki konsep } \\
\text { yang terbalik tersebut }\end{array}$ \\
\hline $\begin{array}{l}\text { Kesalahan penulisan } \\
\text { pada halaman } 11 \text {, } \\
\text { seharusnya menjadi } \\
7: 30 \text { bukan } 7: 80\end{array}$ & $\begin{array}{l}\text { Merevisi } \\
\text { penulisan }\end{array}$ \\
\hline
\end{tabular}


Perbaikan dilakukan berdasarkan saran/komentar dari pakar. Hasil revisi dari pakar materi lebih jelasnya dapat dilihat pada gambar berikut ini:

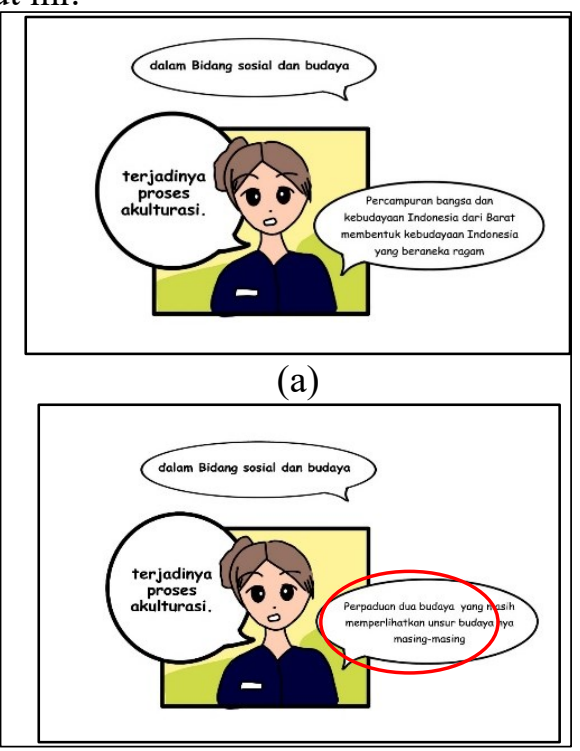

(b)

Gambar 7 : Revisi komik, (a) sebelum, (b) sesudah direvisi

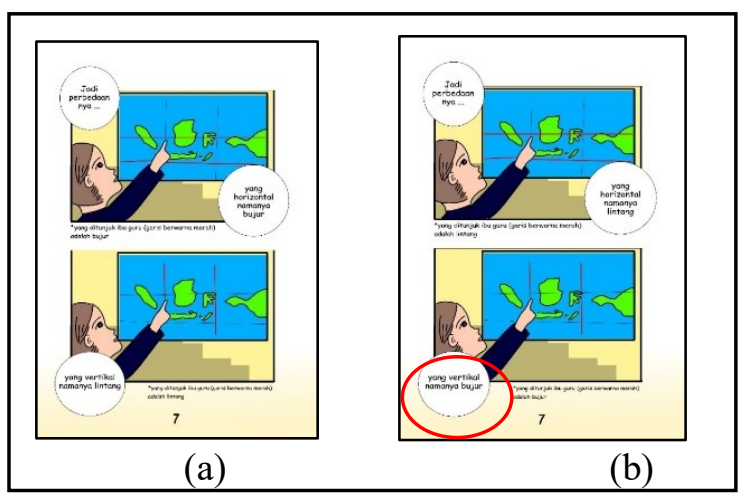

Gambar 8 : Revisi komik, (a) sebelum, (b) sesudah direvisi

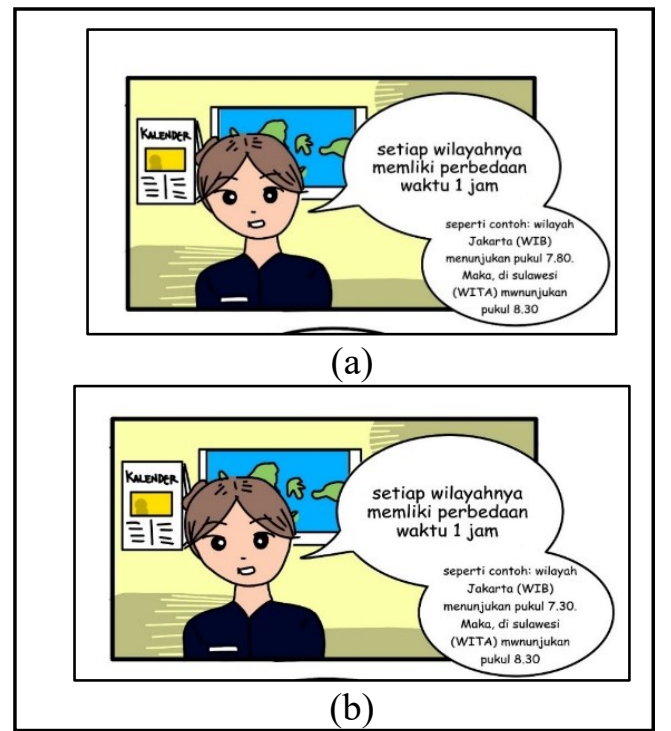

Gambar 9 : Revisi komik, (a) sebelum, (b) sesudah direvisi

Berdasarkan hasil validasi dari ahli materi yaitu Dr. Aris Munandar, M.Si , Dosen Pendidikan Geografi, Universitas Negeri Jakarta memberikan saran untuk perbaikan yaitu untuk halaman nomor 13, konsepnya kurang tepat, seharusnya: perpaduan dua budaya yang masih memperlihatkan unsur budaya masing-masing. Lalu, Kesalahan penulisan pada halaman 11, seharusnya menjadi 7:30 bukan 7:80 dan pada halaman 7, konsep bujur dan lintang terbalik.

\section{Hasil Tanggapan Peserta Didik}

Setelah dilakukannya pre test dan post test secara online, maka dilakukan penyebaran angket ke peserta didik menggunakan google form guna mengetahui bagaimana tanggapan peserta didik mengenai belajar menggunakan komik pada pembelajaran IPS dengan konten geografi. Adapun hasil dari tanggapan peserta didik kelas VII.5 dengan menggunakan angket yaitu sebagai berikut :

\section{Belajar dengan Menggunakan Komik Sangat Menarik}

Tabel 7 : Belajar dengan Menggunakan Komik Sangat Menarik

\begin{tabular}{lcc}
\hline Jawaban & Frekuensi & $\begin{array}{c}\text { Presentase } \\
(\mathbf{\% )}\end{array}$ \\
\hline $\begin{array}{l}\text { Sangat } \\
\text { Setuju }\end{array}$ & 24 & $65 \%$ \\
\hline Setuju & 13 & $35 \%$ \\
\hline $\begin{array}{l}\text { Kurang } \\
\text { Setuju }\end{array}$ & 0 & $0 \%$ \\
\hline Tidak Setuju & 0 & $0 \%$ \\
\hline Total & 37 & $100 \%$ \\
\hline
\end{tabular}

Tabel 7, menjelaskan bahwa peserta didik kelas VII.5 di SMP Negeri 62 Jakarta sebanyak 24 responden atau $65 \%$ menjawab sangat setuju dan 13 responden atau 35\% menjawab setuju jika belajar menggunakan komik sangat menarik. 
Angelina, dkk. Pemanfaatan Bahan Ajar Berupa Komik ...

Komik Mempermudah Dalam Mempelajari Materi

Tabel 8 : Komik Mempermudah dalam Mempelajari Materi

\begin{tabular}{lcc}
\hline Jawaban & Frekuensi & $\begin{array}{c}\text { Presentase } \\
(\%)\end{array}$ \\
\hline $\begin{array}{l}\text { Sangat } \\
\text { Setuju }\end{array}$ & 16 & $43 \%$ \\
\hline Setuju & 21 & $57 \%$ \\
\hline $\begin{array}{l}\text { Kurang } \\
\text { Setuju }\end{array}$ & 0 & $0 \%$ \\
\hline $\begin{array}{l}\text { Tidak } \\
\text { Setuju }\end{array}$ & 0 & $0 \%$ \\
\hline Total & 37 & $100 \%$ \\
\hline
\end{tabular}

Dari tabel 8 menjelaskan bahwa peserta didik kelas VII.5 di SMP Negeri 62 Jakarta sebanyak 14 peserta didik atau $38 \%$ menjawab sangat setuju dan 23 peserta didik atau $62 \%$ menjawab setuju dalam komik mempermudah dalam mempelajari materi.

Pembelajaran Menggunakan Komik dapat Merangsang Keingintahuan Mempelajari Materi Lebih Lanjut

Tabel 9 : Pembelajaran Menggunakan Komik dapat Merangsang Keingintahuan Mempelajari Materi Lebih Lanjut

\begin{tabular}{lcc}
\hline Jawaban & Frekuensi & $\begin{array}{c}\text { Presentase } \\
(\%)\end{array}$ \\
\hline $\begin{array}{l}\text { Sangat } \\
\text { Setuju }\end{array}$ & 6 & $16 \%$ \\
\hline Setuju & 31 & $84 \%$ \\
\hline $\begin{array}{l}\text { Kurang } \\
\text { Setuju }\end{array}$ & 0 & $0 \%$ \\
\hline $\begin{array}{l}\text { Tidak } \\
\text { Setuju }\end{array}$ & 0 & $0 \%$ \\
\hline Total & 37 & $100 \%$ \\
\hline
\end{tabular}

Dari tabel 9 menjelaskan bahwa peserta didik kelas VII.5 di SMP Negeri 62 Jakarta sebanyak 6 peserta didik atau $16 \%$ sangat setuju dan 31 peserta didik atau $84 \%$ menjawab setuju dalam pembelajaran menggunakan komik dapat merangsang keingintahuan mempelajari materi lebih lanjut.

\section{Penggunaan Kalimat/Tata Bahasa Mudah Dipahami}

Dari tabel 10 menjelaskan bahwa peserta didik kelas VII.5 di SMP Negeri 62 Jakarta sebanyak 16 peserta didik atau $43 \%$ sangat setuju dan 21 peserta didik atau $57 \%$ menjawab setuju dalam penggunaan kalimat atau tata Bahasa mudah dipahami.

Tabel 10: Penggunaan Kalimat / Tata Bahasa Mudah Dipahami

\begin{tabular}{lcc}
\hline Jawaban & Frekuensi & $\begin{array}{c}\text { Presentase } \\
(\%)\end{array}$ \\
\hline $\begin{array}{l}\text { Sangat } \\
\text { Setuju }\end{array}$ & 14 & $38 \%$ \\
\hline Setuju & 23 & $62 \%$ \\
\hline $\begin{array}{l}\text { Kurang } \\
\text { Setuju }\end{array}$ & 0 & $0 \%$ \\
\hline $\begin{array}{l}\text { Tidak } \\
\text { Setuju }\end{array}$ & 0 & $0 \%$ \\
\hline Total & 37 & $100 \%$ \\
\hline
\end{tabular}

\section{Pembelajaran dengan Menggunakan Komik} Memungkinkan Untuk Belajar Mandiri

Tabel 11 : Pembelajaran dengan Menggunakan Komik Memungkinkan Untuk Belajar Mandiri Jawaban Frekuensi Presentase

\begin{tabular}{lcc} 
& & $(\%)$ \\
\hline $\begin{array}{l}\text { Sangat } \\
\text { Setuju }\end{array}$ & 6 & $16 \%$ \\
\hline Setuju & 31 & $84 \%$ \\
\hline $\begin{array}{l}\text { Kurang } \\
\text { Setuju }\end{array}$ & 0 & $0 \%$ \\
\hline Tidak Setuju & 0 & $0 \%$ \\
\hline Total & 37 & $100 \%$ \\
\hline
\end{tabular}

Dari tabel 11 menjelaskan bahwa peserta didik kelas VII.5 di SMP Negeri 62 Jakarta sebanyak 6 peserta didik atau $16 \%$ sangat setuju dan 31 peserta didik atau $84 \%$ menjawab setuju dalam pembelajaran menggunakan komik memungkikan untuk belajar mandiri.

\section{Komik dapat Menambah / Memperkaya Cara} Belajar

Tabel 12 : Komik dapat Menambah / Memperkaya Cara Belajar

\begin{tabular}{lcc}
\hline \multicolumn{1}{c}{ Jawaban } & Frekuensi & $\begin{array}{c}\text { Presentase } \\
(\%)\end{array}$ \\
\hline $\begin{array}{l}\text { Sangat } \\
\text { Setuju }\end{array}$ & 4 & $11 \%$ \\
\hline Setuju & 33 & $89 \%$ \\
\hline $\begin{array}{l}\text { Kurang } \\
\text { Setuju }\end{array}$ & 0 & $0 \%$ \\
\hline $\begin{array}{l}\text { Tidak } \\
\text { Setuju }\end{array}$ & 0 & $0 \%$ \\
\hline Total & 37 & $100 \%$ \\
\hline
\end{tabular}


Dari tabel 12 menjelaskan bahwa peserta didik kelas VII.5 di SMP Negeri 62 Jakarta sebanyak 4 peserta didik atau $11 \%$ sangat setuju dan 33 peserta didik atau $89 \%$ menjawab setuju, yaitu komik dapat menambah atau memperkaya cara belajar.

Komik dapat Digunakan Sebagai Sumber Belajar Alternatif

Tabel 1 : Komik Dapat digunakan Sebagai Sumber Belajar Alternatif

\begin{tabular}{lcc}
\hline Jawaban & Frekuensi & $\begin{array}{c}\text { Presentase } \\
(\%)\end{array}$ \\
\hline $\begin{array}{l}\text { Sangat } \\
\text { Setuju }\end{array}$ & 7 & $19 \%$ \\
\hline Setuju & 30 & $81 \%$ \\
\hline $\begin{array}{l}\text { Kurang } \\
\text { Setuju }\end{array}$ & 0 & $0 \%$ \\
\hline $\begin{array}{l}\text { Tidak } \\
\text { Setuju }\end{array}$ & 0 & $0 \%$ \\
\hline Total & 37 & $100 \%$ \\
\hline
\end{tabular}

Dari tabel diatas menjelaskan bahwa peserta didik kelas VII.5 di SMP Negeri 62 Jakarta sebanyak 7 peserta didik atau $19 \%$ sangat setuju dan 30 peserta didik atau $81 \%$ menjawab setuju dalam pembelajaran menggunakan komik dapat digunakan sebagai sumber belajar alternatif.

Komposisi Penggunaan Gambar dan Tulisan Komik Sesuai dengan Keperluan

Tabel 14 : komposisi penggunaan gambar dan tulisan sesuai dengan keperluan

\begin{tabular}{lcc}
\hline Jawaban & Frekuensi & $\begin{array}{c}\text { Presentase } \\
(\%)\end{array}$ \\
\hline $\begin{array}{l}\text { Sangat } \\
\text { Setuju }\end{array}$ & 1 & $3 \%$ \\
\hline Setuju & 27 & $73 \%$ \\
\hline $\begin{array}{l}\text { Kurang } \\
\text { Setuju }\end{array}$ & 9 & $24 \%$ \\
\hline $\begin{array}{l}\text { Tidak } \\
\text { Setuju }\end{array}$ & 0 & $0 \%$ \\
\hline Total & 37 & $100 \%$ \\
\hline
\end{tabular}

Dari tabel diatas menjelaskan bahwa peserta didik kelas VII.5 di SMP Negeri 62 Jakarta sebanyak 1 peserta didik atau $3 \%$ sangat setuju, 27 peserta didik atau $73 \%$ menjawab setuju dan 9 peserta didik atau 24\% menjawab kurang setuju dalam komposisi penggunaan gambar dan tulisan sesuai dengan keperluan.

Selama Penggunaan Komik, Tidak Mengalami Kesulitan / Kendala yang Cukup Berarti

Tabel 15 : Selama Penggunaan Komik Tidak Mengalami Kesulitan / Kendala yang Cukup Berarti

\begin{tabular}{lcc}
\hline Jawaban & Frekuensi & $\begin{array}{c}\text { Presentase } \\
(\%)\end{array}$ \\
\hline $\begin{array}{l}\text { Sangat } \\
\text { Setuju }\end{array}$ & 1 & $3 \%$ \\
\hline Setuju & 36 & $97 \%$ \\
\hline $\begin{array}{l}\text { Kurang } \\
\text { Setuju }\end{array}$ & 0 & $0 \%$ \\
\hline Tidak Setuju & 0 & $0 \%$ \\
\hline Total & 37 & $100 \%$ \\
\hline
\end{tabular}

Dari tabel diatas menjelaskan bahwa peserta didik kelas VII.5 di SMP Negeri 62 Jakarta sebanyak 1 peserta didik atau $3 \%$ sangat setuju dan 36 peserta didik atau 97\% menjawab setuju selama penggunaan komik, peserta didik tidak mengalami kesulitan atau kendala yang cukup berarti.

\section{Komik Meningkatkan Pengetahuan tentang Materi yang Dipelajari}

Tabel 16 : Komik Meningkatkan Pengetahuan tentang Materi yang Dipelajari

\begin{tabular}{lcc}
\hline Jawaban & Frekuensi & $\begin{array}{c}\text { Presentase } \\
(\%)\end{array}$ \\
\hline $\begin{array}{l}\text { Sangat } \\
\text { Setuju }\end{array}$ & 1 & $3 \%$ \\
\hline Setuju & 36 & $97 \%$ \\
\hline $\begin{array}{l}\text { Kurang } \\
\text { Setuju }\end{array}$ & 0 & $0 \%$ \\
\hline Tidak Setuju & 0 & $0 \%$ \\
\hline Total & 37 & $100 \%$ \\
\hline
\end{tabular}


Angelina, dkk. Pemanfaatan Bahan Ajar Berupa Komik ...

Dari tabel diatas menjelaskan bahwa peserta didik kelas VII.5 di SMP Negeri 62 Jakarta sebanyak 1 peser ta didik atau $3 \%$ sangat setuju dan 36 peserta didik atau 97\% menjawab setuju komik meningkatkan pengetahuan tentang materi yang dipelajari. Adapun hasil tanggapan dari kuesioner melalui google form dapat dilihat di lampiran. Dari beberapa tabel diatas dapat disimpulkan, bahwa pemanfaatan komik sebagai bahan ajar sangat layak karena berdasarkan analisis data melalui perhitungan persentase menunjukkan hasil $80 \%$ (layak)

\section{Hasil Belajar Peserta Didik}

Penilaian hasil belajar peserta didik dinilai dengan menggunakan soal pre-test dan post-test. Hal ini bertujuan untuk mengukur seberapa besar pemanfaatan bahan ajar berupa komik dalam mata pelajaran IPS dengan konten geografi terhadap hasil belajar siswa. Adapun rekapitulasi pre test dan post test adalah sebagai berikut :

Tabel 2 : rekapitulasi rata-rata nilai pre test dan post test

\begin{tabular}{clcc}
\hline No. & Keterangan & $\begin{array}{c}\text { Pre } \\
\text { test }\end{array}$ & Post test \\
\hline 1. & Jumlah siswa & 37 & 37 \\
\hline $\mathbf{2 .}$ & $\begin{array}{l}\text { Rata-rata } \\
\text { nilai }\end{array}$ & 58.37 & 94.18 \\
\hline 3. & $\begin{array}{l}\text { Nilai } \\
\text { terendah }\end{array}$ & 25 & 65 \\
\hline $\mathbf{4 .}$ & $\begin{array}{l}\text { Nilai } \\
\text { tertinggi }\end{array}$ & 95 & 100 \\
\hline $\mathbf{5 .}$ & $\begin{array}{l}\text { Jumlah siswa } \\
\text { tuntas }\end{array}$ & 7 & 34 \\
\hline $\mathbf{6 .}$ & $\begin{array}{l}\text { Jumlah siswa } \\
\text { tidak tuntas }\end{array}$ & 30 & 3 \\
\hline & & & \\
\hline
\end{tabular}

Berdasarkan tabel diatas, dengan menggunakan rumus uji gain yaitu yang dilakukan untuk mengetahui tingkat atau besarnya pengaruh penggunaan / pemanfaatan media komik dengan menghitung selisih skor pada saat posttest dan pretest, maka perhitungan persentase menunjukkan data 0.8 (kategori tinggi). Dari hasil perhitungan tersebut, dapat dilihat dari pengklasifikasian hasil nilai ke dalam kriteria gain skor bahwa hasil menunjukan 0.8 yang berarti adanya pengaruh yang tinggi dalam penggunaan komik pada saat dilakukan posttest dan pretest.

\section{SIMPULAN DAN SARAN}

Berdasarkan hasil penelitian dan pembahasan yang dipaparkan, maka dapar ditarik kesimpulan yaitu: (1) Komik geografi untuk kelas VII SMP Negeri 62 Jakarta, berdasarkan validasi oleh ahli komik dan ahli materi dinyatakan layak digunakan sebagai bahan ajar dalam proses pembelajaran IPS dengan konten geografi; (2) Adanya pengaruh penggunaan komik dalam pembelajaran IPS dengan konten geografi. Hal tersebut dapat dilihat dari perhitungan melalui uji gain dan skala likert. Hasil menunjukan adanya perbedaan yang signifikan setelah menggunakan komik dalam pembelajaran IPS dengan konten geografi di kelas VII.5 SMP Negeri 62 Jakarta. Hal tersebut dapat dilihat dari hasil pretest dan post test yang menunjukan kategori tinggi yaitu 0.8 dalam perhitungan uji gain. Selanjutnya melalui perhitungan skala likert, melalui presentase jawaban responden yaitu menunjukan sebesar $80 \%$ yang termasuk kategori layak.

Berdasarkan dari hasil penelitian yang dilakukan, penulis ingin mengutarakan saran yaitu dalam kegiatan pembelajaran, peserta didik diharapkan akan lebih aktif sesuai dengan penggunaan yang guru siapkan. Sehingga, peserta didik memiliki minat, motivasi dan hasil belajarnya baik. Melalui menggunakan komik, Peserta didik dapat membaca dan memahami isi dengan cara yang menyenangkan dan hasil belajar pun akan meningkat lebih baik. Lalu, penelitian ini dapat dikembangkan oleh penelitian selanjutnya dan dapat dikembangkan baik dari segi visual maupun dalam pembelajarannya agar dapat menjadi suatu bahan ajar yang amat layak.

\section{DAFTAR RUJUKAN}

Arikunto, Suharsimi. 2006. Prosedur Penelitiaan: Suatu Pendekatan Praktik. Jakarta: PT. Rineka Cipta.

Desi Kurniati, dkk. 2017. Efektivitas Media Komik Pada Materi Sifat-Sifat Bangun Ruang Untuk Siswa Kelas V SD Negeri 6 Kota Bengkulu. Jurnal Penelitian Pembelajaran Matematika Sekolah (JP2MS), Vol. 1, No. 1

Jufri Ahmat dan Wahyu Sukartiningsih. 2013. Penggunaan Media Komik Untuk Meningkatkan Keterampilan Membaca 
Cerita Di Kelas V Sekolah Dasar. JPGSD. Volume 01 Nomor 02: 0-216

Olynda Ade Arisma. (Universitas Negeri Malang, 2012) Peningkatan Minat dan Kemampuan Membaca Melalui Penerapan Program Jam Baca Sekolah di Kelas VII SMP Negeri 1 Puri.

Santi Andrayani (Universitas Islam Negeri Raden Intan Lampung, 2017) Pengembangan media komik pada mata pelajaran IPS Sekolah Dasar Kelas V

Saputro, Anip Dwi. 2015. Aplikasi Komik Sebagai Media Pembelajaran. M U A D D I B. Vol.05 No.01

Sugiyono. 2013. Metode Penelitian Pendidikan, Pendekatan Kuantitatif, Kualitatif, dan $R \& D$. Bandung: Alfabeta.

Undang-undnag sistem pendidikan nasional, No. 20 tahun 2003 pasal 1 ayat 1 , diakses dari http://lldikti3.ristekdikti.go.id/html/wpcontent/uploads/2011/04/sisdiknas.pdf , diakses pada tanggal 26 Mei 2020.

Zuli Lailatul Fajriah dan Evita Anggereini. 2016. Pengembangan Edu Komik Sebagai Bahan Ajar Berbasis Pendidikan Karakter Pada Materi Interaksi Mahluk Hidup dan Lingkungannya di Sekolah Menengah Pertama. Jurnal BIODIK. Volume II. Nomor 1. ISSN 2460-2612 